\title{
Bridging the Gaps: Integrating Archaeology and History in Oaxaca, Mexico. \\ Danny Zborover and Peter C. Kroefges, eds. Boulder: University Press of \\ Colorado, 2015, 416 pp. \$75.00, cloth. ISBN 978-1607323280.
}

This work is the first book-length monograph to address how documentary sources and archaeological data can and should be used in tandem to contribute to a richer, more robust historical interpretation of transconquest Oaxaca. In the ancient past, Oaxaca was the center of production of various long-standing literary traditions, recorded in such diverse places as codices, stone carvings, sculpture, lienzos, Spanish chronicles, and colonial government documents. Such writings contribute a wealth of information about indigenous knowledge systems and help us understand the processes and impacts of multiple conquests and colonialism in this part of the Mesoamerican world. The authors argue that documents, although enormously informative, record particular, limited, and often elite versions of past events and thus can only get us so far. Archaeological data and oral histories allow researchers to investigate everyday economics, social interactions, and political processes that may or may not have made their way into the written record. The volume's authors each tell a more complete, long-term history utilizing "multimedia” sources of data (sensu König and Sellen, Chapter 15), including literary work and inscriptions in various forms, oral histories, and diverse sets of archaeological data.

The coverage is broad and includes most of Oaxaca's major culture areas-the Mixteca Alta, Mixteca Baja, the Pacific coast, the Isthmus of Tehuantepec, the Valley of Oaxaca, the Sierra Norte, and the Sierra Sur. Many authors acknowledge the challenge of connecting historical events, which are often short-term and episodic, with the longue durée that archaeology provides, but in the end all argue the relationship between these sources should be one of partnership. Although discrepancies based on different kinds of data cannot easily be tested, each source must be evaluated and used critically in its own right for the kind of information that it provides. Each chapter thus makes a unique contribution on the themes of settlement history, elite traditions, conquest and colonialism, political machinations, and contemporary practices.

Oaxaca is famous for long-standing cultural continuity of multiple indigenous language speaking peoples, and the volume shows how incredibly diverse each individual region and territory was. This is highlighted perhaps most effectively by Rincón Mautner, who covers a region that was always "pluriethnic." Zborover, Whittington and Workinger, and Kroefges tackle this same theme, demonstrating the rich and complex cultural history of Oaxaca's diverse peoples, who endured multiple conquests and colonialisms. Chapters by Zeitlin, van Doesburg and Spores, Byland et al., Jiménez Osorio and Posselt Santoyo, and Spores serve as laudatory and constructive examples of how juxtaposing and integrating multiple sources leads to 
better reconstructions of Mesoamerican history. The volume also recognizes and celebrates the relevance that historical archaeology has for contemporary communities in Oaxaca and beyond (especially König and Zborover). Zborover provides a thorough introduction that lays the theoretical groundwork and places Mesoamerican methods of integrating history and archaeology within (or alongside) U.S. and global historical archaeologies, arguing that Oaxacanists have been doing this kind of research since Alfonso Caso first linked Zapotec inscriptions with historical texts such as codices in the 1930s. Zborover argues that integrative research is more "seamlessly" accomplished by Mexican and European-trained scholars, whose disciplinary homes are less rigidly separated, and laments that Oaxaca scholars have not engaged sufficiently with interdisciplinary "historical archaeologies" accomplished outside Oaxaca. He would also like to see historical archaeologies in Oaxaca move beyond Zapotec and Mixtec histories to address Oaxaca's minority languages and cultures (chapters by Zborover, Kroefges, and Rincón Mautner). Finally, I would be remiss not to mention the excellent tribute and retrospective on the work of Bruce Byland by Pohl and McCafferty, along with Pohl's effort to (posthumously) prepare the text of Byland's presentation for publication, which is both revealing and reflectively self-critical.

The one major misstep, I think, is the selection of the cover image for the volume, which is a photograph of an elaborately carved human mandible. Even my own students were quick to note the odd choice; I don't think it captures what the volume is about. Nor does it send the right message amid global "decolonizing" practices in our field. The SAA symposium on which this volume is based took place in 2007, and the delay in publication is evident in the small number of citations to relevant, post-2007 work in Oaxaca and beyond, which could (and should) now be included. Nevertheless, the volume is an important contribution that draws attention to the excellent "multidisciplinary" work (sensu König, Chapter 3) being done in Mesoamerica. I hope that readers will seek out these and other historical and archaeological contributions that Oaxacanist anthropologists continue to make to our understanding of Oaxaca's diverse past and present.

STACIE M. KING, Indiana University 